\title{
Memory-politics and neo-nationalism: Trianon as mythomoteur
}

\section{Margit Feischmidt, dr}

Hungarian Academy of Sciences, Research Center for Social Sciences, Minority Studies Institute, Budapest, senior researcher http://kisebbsegkutato.tk.mta.hu/en/researcher/feischmidt-margit

\begin{abstract}
Analysing the newly emerged Trianon-cult this paper argues that the current wave of memory-politics became the engine of new forms of nationalism in Hungary constituted by extremist and moderate right wing civic and political actors. Following social anthropologists Gingrich and Banks the term neo-nationalism will be applied and linked with the concept mythomotoeur' of John Armstrong and Anthony D. Smith emphasizing the role of pre-existing ethno-symbolic resources or mythomoteurs in the resurgence of nationalism. A special attention will be given to elites who play a major role in constructing new discourses of the nation and seek to control collective memories, taking their diverse intentions, agendas and strategies specifically into consideration. This "view from above" will be complemented with a "view from bellow" by investigating the meanings that audiences give to and the uses they make of these memories. Thus, the analysis has three dimensions: it starts with the analysis of symbols, topics and arguments applied by public Trianon discourses; it continues with the analysis of everyday perceptions, memory and identity concerns; and finally ends with an anthropological interpretation of memory-politics regarding a new form of nationalism arising in the context of propelling and mainstreaming populist right-wing politics. The main argument of the paper is that the Hungarian Trianon-cult identified as national mythomoteur although invokes a historical trauma but rather speaks to current feelings of loss and disenfranchisement, offering symbolic compensation through the transference of historical glory, pride, and self-esteem within a mythological framework. The paper is part of a larger effort to understand the cultural logic and social support of new forms of nationalism in Hungary propelled by the populist far right.
\end{abstract}

\section{Keywords}

History, memory, commemoration, memory politics, nationalism, neo-nationalism, discourse, Hungary, Eastern Europe, Central Europe

\section{Introduction. Memory-politics and neo-nationalism}

Issues related to the past and its commemoration re-emerged as pressing concerns at the moment when the young Hungarian democracy began to exhibit serious signs of crisis. The signs of this renewed preoccupation with the past are manifold. They range from the overburdening of legal and political discourses with historical references, through the erection of hundreds of new statues all over the country, to the commemoration of historical events that were irrelevant or in some cases even unacknowledged. Nevertheless, this was not the first time that historical symbols acquired an importance in Hungary's post-communist history. Historical revisionism and commemorative practices had contributed to the symbolic breakdown of the communist system (Gal, 1991; Hofer, 1991; Hann, 1990; Zempléni, 2002; Verdery, 1999) and created new ways of legitimization in a situation where former mechanisms of legitimacy (...) have suddenly ceased to operate (Gyáni 1993: 902-3). The "search for a usable past" supported mainly the revival of national myths, symbols and 
narratives - of the "the memory-nation connection." (Olick, 1998) However, as a case study analysing the 150 anniversaries of the revolutions in 1848 revealed, the concept of democracy and common European values were also symbolically legitimized - though with varying effects - through historical references to historical moments of pre-communist times. (Brubaker and Feischmidt, 2002)

A specific relation to the past which anthropologists have exposed in recent years is the nostalgia of state socialism. Moreover, they claimed that as much the Holocaust becomes a paradigm for research in memory studies, works on nostalgia are paradigmatically East European (Todorova and Gille 2010, Ange and Berliner 2015) Furthermore a causal relationship between the nostalgia of socialism and rampant feelings of insecurity and disenfranchisement have been identified. In her path-breaking work on post-communist nostalgia, Daphne Berdahl conceptualized Ostalgie as a form of resistance. (Berdahl, 2010)

This paper focuses on a newer wave of memory-politics- one that commemorates national trauma and defeat partially following the logic of ethnic mythologies of the immediate post-socialist period and partially fitting to the "fabric of nostalgia" anchored in collective feelings of loss of the last decade. Colovic and Zubrzycki have identified the power of symbolic actions and mythologies in resurgence of Serbian and Polish nationalism as well as in legitimizing radical political changes in these countries far before us. (Zubrzycki 2006, 2011; Colovic 2002) A similar fundamental political transformation has been legitimized more recently in Turkey by reinterpreting the founding moments of the Turkish nation and reshaping the public understanding of its history. (Cinar and Has, 2017) Similarly Chris Hann has proven (using the example of Ópusztaszer) how politicians manipulate the national past in Hungary to authenticate the political representation of a national grandeur. (Hann 2015)

This paper argues that the current wave of memory-politics became the engine of new forms of nationalism in Hungary constituted by extremist and moderate right wing civic and political actors. Following social anthropologists Gingrich and Banks the term neo-nationalism will be applied, which emphasizes the re-emergence of nationalism in relation to far right populist politics and to symbolic strategies manipulating notions of national culture and history (Gingrich-Banks 2006: 6) Nevertheless, to understand the connection of memory politics to re-emergence of nationalism an old concept of nationalism studies will be applied: mythomotoeur or myth-symbol complex. The term was introduced by John Armstrong indicating the vital role of myths and symbols (Armstrong 1982) and further developed by Anthony Smith to mark the centrality and continuity of constitutive myths (Smith 1988). In a later book Smith emphasizes the role of pre-existing ethno-symbolic resources or mythomoteurs in the resurgence of nationalism (Smith 1999, 253). Following the late Anthony Smith and further constructivist scholars, I will pay special attention to elites who play a major role in constructing new discourses of the nation and seek to represent collective memories, taking their diverse intentions, agendas and strategies specifically into consideration. (Fox, 2014; Smith, 2014) This "view from above" will be complemented with a "view from bellow" by investigating the meanings that audiences give to and the uses they make of these memories.

Chris Hann recently analysed the recovery of the national mythomoteur in the context of a particular Hungarian village. My theoretical ambition is similar, though with a somewhat different methodology. Instead of focusing on one locality, I will concentrate on a single issue of memory politics: the reemergence of the discourse on "national trauma" in relation to the Trianon Treaty and the historical nostalgia related to the pre-Trianon "golden age" of the nation that is symbolized as "Greater Hungary." Although I consider the investigations pursued by critical historiographers relevant to this analysis, my approach differs also from theirs. A social anthropological perspective will be applied by focusing on objects of memory politics (commemorative events, historical myths and symbols) as well as its agents. Everyday discourses will be also examined taking in consideration structural abilities of 
the post-communist, neo-capitalist context. Moreover the problem of how memory-politics propels new forms of nationalism as well as its impact on national identity will be also addressed.

Finally, there is an effort to analyse the Hungarian case in a comparative framework by showing how a semi-peripheral capitalism characterized by a shortage of other resources seeks to create symbolic capital through the manipulation of the past and the production of its mythic visions. The paper's second section will provide a short overview of the discursive field wherein divergent representations of Trianon are produced. This overview will be followed by four subsequent sections that deal with different actors who are involved in recovery of the Trianon mythomotoeur. I begin by briefly addressing the memory-politics of the state (section three) and academic discourses (section four), before devoting attention to discourses of public history (section five) and far-right politics (section six). My main argument is that various far-right organizations decisively shaped the Trianon-discourse and used it as a tool to subvert the basic political consensus and taboos of the post-communist period. While the intentions of these groups have thus far prevailed, there also other actors who seek to offer a less radical interpretation and move the symbol towards the political mainstream by focusing attention on the present-day dispersion of the Hungarians and calling for an ethnic perception of the nation. The last part of the paper will analyze various semi-public discourses of everyday actors. Based on this data a neo-Durkheimian explanation of historical nostalgia is adopted which says that the Trianon-cult although invokes a historical trauma but rather speaks to current feelings of loss and disenfranchisement, offering symbolic compensation through the transference of historical glory, pride, and self-esteem within a mythological framework.

\section{Memory-politics in Hungary. Strategies and agencies of the Trianon-discourse}

Hungary lost large territories (along with two-third of its population) after the First World War. The Trianon Treaty (signed in 1920) left a long-lasting impact on historical consciousness as well as national identity. This is evident from the oft-cited phrase "Magyar az, akinek, fáj Trianon" (A Hungarian is someone who grieves Trianon), which also highlights the emotional charge carried by the historical trauma.

Hungarian scholars identified two antagonistic strategies that political elites have later adopted in relation to Trianon. They claim that elites have alternated between an effort to maintain the topic "on the agenda" (interwar period) and an attempt to "silence" the issue (communist period). However, According to Vásárhelyi, the regime change brought about a novel situation in that the two strategies were simultaneously present in the Hungarian public sphere after 1989 (Vásárhelyi, 2007). Historian Gergely Romsics (2006: 50) came to a similar conclusion. Analyzing parliamentary speeches between 1990 and 2002, he concluded that there is a clear distinction between the right-wing rhetoric (which emphasizes historical grievances from an ethnic and/or historical point of view) and the left-liberal discourse (which focuses on the topic's negative impact on society).

I myself have come to think of Trianon discourses in a slightly more complex way. One discursive strategy is the detachment from the emotional aspects of the historical event which is related either to a past-oriented approach (its proponents emphasize the historical causes of the territorial division); or to a more present-oriented approach which denies nostalgia by a pragmatic acceptance of territorial division. The other discursive strategy consists in elevating the Trianon-discourse into the emotive and symbolic domain with a view to evading a clash with pragmatic pressures. This strategy can also be related with a past- or a present-oriented approach. The former strives to recover the national unity through a re-enactment of a mythical past. The latter seeks to displace the loss and grief caused by 
Trianon by portraying ethnic Hungarians who became citizens of neighboring countries as suffering victims and to overcome the separation by enacting rituals of reunification.

These approaches tend to be followed by different types of actors (although it is not possible to neatly match approaches with actors). I will begin my analysis with the Hungarian state, which has vacillated between embracing and denying the Trianon-trauma before settling for an in-between position after 1989. However, the state has recently shifted strategy when the new right-wing government led by the Fidesz party officially embraced the Trianon-trauma after 2010. Academics were critical of such attempts due to the emotional detachment that characterizes scholarly practice. The majority of historians, however, also admit that they have adopted a special position in relation to Trianon. This has to do with the fact that the influence exercised by other actors renders an objectivist stance very hard to sustain. One such category of actors that I will analyze is constituted by the agents of public history who exert significant influence through the maintenance of memorial houses, the publication of historical magazines and the building of a nostalgia-industry. These actors are, however, not alone on the turf of myth-building. The civic and political organizations situated on the far-right end of the ideological spectrum were the first to initiate public events on the Trianon-topic and these actors continued to dominate commemorative activities by recent times when the nationalist government has appropriated it successfully. In what follows, I will analyze the symbolic work performed by each of these actors and also seek to show how their strategies and achievements influenced each other.

\section{Mainstreaming Trianon: the Hungarian state celebrating the extraterritorial nation}

Without doubt the most significant recent change in the public memory of Trianon is a remarkable shift in the discourse of the Hungarian state. This is part of a more general shift in the direction of identity politics. This shift is most clearly visible in the new Fundamental Law whose Preamble identifies national values and traditions as the foundations of the political community. Here, I would like to emphasize the new law, whereby "the National Assembly declare[d] the 4th of June, the day of the enforced Peace Treaty of Trianon of 1920, a Day of National Cohesion.” (Act No. 45 of 2010)

The preamble of the Law on the Testimony for National Cohesion" calls the "Peace Treaty signed on the 4th of June, 1920 ... one of the greatest tragedies of Hungarian history" and emphasizes the "political, economic, legal, and psychological problems [that] remain unresolved to this day." "The second section of the law takes a stance both against revisionist politics (pursued by the far-right) and universalism (pursued by the leftliberal elite). The third section asserts the existence of a "single Hungarian nation" and states that the unity of Hungarian individuals and communities should be based on "crossborder cohesion." The fourth section attempts to connect regret for lost territorial integrity with historical self-criticism and declares a "national commitment" towards the minority communities living outside the current territory of the state: "The Hungarian National Assembly feels obliged to call upon present members of the Hungarian nation and those of future generations to strive for national cohesion (...)."

In the speech he gave at the first official commemoration of the Memorial Day for the Treaty of Trianon, former president László Sólyom emphasized the event's decisive influence on Hungarian national identity, Hungary's relationship with crossborder Hungarian minority communities and various peoples living in neighbouring countries. He pointed out that the significance of the commemoration resides in its effort to nurture a sense of unity: "The Hungarian nation exists through the cultural nation in Hungary, the mother country, through the autochthonous Hungarian communities in the neighbouring countries, and through the Hungarian diaspora throughout the world. Hungary on the other hand is also a multinational country that recognizes its national and ethnic minorities as being constituent parts of the state. Our position thus comes with numerous responsibilities. As we now declare our unity, it is paramount to identify the present-day genuine structure 
of our nation, the pending tasks of the mother country, and the various needs of the minority communities abroad. However, having the knowledge and the will-power is not sufficient. We also need to resolve the emotive dimension in the two-fold task of upholding our national unity and improving our relation with neighbouring peoples. In this, too, we need to seek for a new path." "ii

The text of the law and the presidential speech mirror a clear tendency to promote a Hungarian national identity defined by historical traditions and ethno-linguistic commonality as opposed to a citizenship-based national community. In this sense, the celebration of National Cohesion constitutes a foundational event, which — through its yearly commemoration-reinforces the legitimacy of the concept of ethnic citizenship. It is important to note that this concept was later codified into law through the reform of the citizenship law ${ }^{\text {iiii. }}$. These two legal texts, together with the choreography of the official commemoration of Trianon, have cast a shadow over the existing geo-political status quo in the Carpathian Basin.

The ambiguity of the historical legacy and of the nation's ethnicization have continued to characterize the memory-politics of the right-wing government in the past years. The self-reflexive tone introduced by László Sóyom - has, however, all but disappeared. The same has happened with a later endeavour: that of incorporating professional discourses into the state's memory-politics. This is, for instance, evidenced by a permanent exhibition entitled "We, the Hungarians" (Mi, magyarok) inaugurated in 2015 but closed two years later without any explanation. The exhibition was hosted by The House of Hungarianness (Magyarság Háza), iv a public institution devoted to supporting the development of "Hungarian-Hungarian relations" and the promotion of "national values". "The exhibition strived to transcend the tragic view of the nation by emphasizing past achievements and linking them to the challenges of the present. Combining new perspectives with new technologies and an emphasis on everyday life, the exhibition was achieving a high degree of interactivity ${ }^{\mathrm{vi}}$.

As mentioned before, the current conservative government has appropriated the historical legacy of Trianon. This still true, though there are clear evidences that memory politics and historical nostalgia became less important in public discourses on the nation than the discourses on enemies made topical with references to the threat of migration since 2015. The nationalisation of the public memory of Trianon has been achieved by a historical narrative focused on national pride anchored in the preTrianon period and by promoting the ethnic bond unifying Hungarians living in and outside the current borders of the country. In the latter case, ethnic unity is evoked through the celebration of various historical symbols that were invented by late nineteen century romantic nationalists. The mythic bird, the Turul, is one of the key symbols of this ethnic mythology. In a speech he gave at the Ópusztaszer memorial, prime minister Orbán alluded to the bird's role in the healing of the Trianontrauma. "It [the Turul] reminds us that every Hungarian is responsible for every other Hungarian. The Hungarian nation is a world nation because the boundaries of the country do not coincide with those of the nation... This statue tell us that there is only one country, which is capable of uniting all Hungarians on both sides of the Trianon border into a single community. (Hann, 2015: 141 vii) "The future which overwrites Trianon has started" is the title of a commemorative article published on the website of Kurultaj, "the annual assembly of the Hun-Turkic nations", viii an event inspired by the interwar idea of Turanism celebrating the Eastern ancestry and kinship of the Hungarians. Seen from the perspective of the unity of "Turanic" nations celebrated in Opusztaszer and Bugac the home country from where the Hungarians join this unity and aspires to be its leader is not Hungary as a political unit but the "Carpathian-basin" as a naturalized ethnic unit. ${ }^{\text {ix }}$

This section has addressed the radical shift of state politics towards issues of memory, emphasizing how Trianon was used to legitimize the ethnic reconceptualization of the nation. I highlighted two divergent ways of representing the nation: through the symbols of ethnic mythology (exemplified by 
the prime-minister's reference to the Turul) and through the link to modernity (exemplified by the fugitive exhibition "We, the Hungarians" and the speech of the former state president) claiming the clear prioritization of the former in the last years. The next section will address the intellectual sources of the historical discourse.

\section{Divergent academic approaches to the "Trianon-trauma"}

Trianon was always in the focus of Hungarian historiography and this very intense academic interest generated manifold controversies and debates. Historian Ignác Romsics gives a short outline of dominant historiographic perspectives on Trianon during three important periods of the twentieth century: the Horthy-period, the coalition period (1945-1947), and the Kádár-period. He shows that the revisionist politics of the Horthy-regime were supported by two types of argumentation: a historical narrative promoting the cultural and political superiority of Hungarians and a discourse which combined ethnic and geographic notions in order to present "the Central-Danube Basin" as a unitary region from a geopolitical and economic point of view (Romsics, 2010: 8-9). The coalition period was characterized by the dominance of a critical perspective, which addressed the negative consequences of the revisionist era. In the first decades of state-socialism the goal of "reckoning with our own revisionists and chauvinists" over-ruled all other interpretative attempts. Perspectives emphasizing the need for a release from the trauma caused by wartime losses - together with the assumption of responsibility for crossborder Hungarian minorities - only returned into Hungarian politics and public discourse in the 1970s. Most of the historians working on this topic agree that the present-day engagement with Trianon is motivated by the actual trauma which was preserved in social memory and forms an integral part of national identity. Scholars have also highlighted that the symbol has become connected to the cause of Hungarian minority communities and stressed that historians cannot disregard this relationship.

Not all scholars agree with this interpretation. Refuting the 'continuity thesis', sociologist and historian Éva Kovács has articulated a radically different interpretation for the survival of the trauma: "One can easily see, that for long time now, the memory of Trianon has not been fueled by our first-hand experience nor been part of our communicative memory. There is almost no one left to remember Trianon personally. What we know today about Trianon comes from cultural memory. Trianon has become a lieu de mémoire (Pierre Nora) and a part of memory politics. As a consequence, the various uses of Trianon belong to an ideology which appropriates historical debates to be instrumentalized in the service of politics, giving a new shape to existing attitudes. Unfortunately, in our case these attitudes do not enhance a disposition towards patriotism, but intensify the feelings of xenophobia, revanche, and ressentiment which can be found more or less in all societies." (Kovács, 2010: 50)

Kovács's argument is that the popular public history discourse on Trianon - which she calls "Trianonizing"- serves as an instrument for clouding or side-lining the unsettling memory of the Holocaust. Gábor Gyáni agrees with Éva Kovács regarding the close connection between the persistent significance of the Trianon-cult and the unsettling memory of the Holocaust. He, however, proposes an alternative explanation for the popularity of Trianon: "there is no other historical referent in Hungarian history [aside Trianon], which could assume the function of the quintessential Hungarian lieu de mémoire." (Gyáni, 2012, translation mine).

An outstanding achievement in the creation of lieux de memoire is the volume edited by the historian Miklós Zeidler and published in 2003 as the second tome of the Nation and Memory series. This volume contains the most comprehensive collection of historical sources about the First World War, including documents of the Peace Conference and Peace Treaty in Paris, as well as material on the revisionist politics that prepared the field for the Treaties of Vienna (1938 and 1940). The second part of this 
monumental work deals with the political and public memory of Trianon in the interwar period and after the Second World War - covering the search for alternative political visions, essays written by public intellectuals, alongside documents from the popular culture of revisionism. The volume also contains a separate chapter on "scientific memory" (covering the main issues and approaches of academic work dealing with Trianon) and some newer studies investigating the cultural memory of Trianon (Trianon in historical consciousness; Trianon as national trauma; Trianon in literature, Trianon legends, Trianon in popular culture). Approaching to the 100 anniversary of the Peace Conference and Treaty in Paris the Hungarian Academy of Sciences launched a research program which according his leader, the historian Balázs Ablonczy ${ }^{x}$ promotes new research on social consequences of the Trianon Treaty affecting local societies and international relations in the region, as well as publication promoting transnational professional discourse.

There is a close relationship between the memory of Trianon and Hungarian nationalism. Most of the above referred authors agree that Trianon is a lieu de memoire endowed with the potential of becoming a central political symbol. But when? - one could ask, taking inspiration from the classic question of nationalism studies ("When is the nation?"). In relation to the latest revival Zeidler reiterated the important link between the resurgence of "Trianonization" and nationalism as a political project: "In the midst of the heated public discussions that took place in the period of the political transition Trianon was once again resurrected as a public and political issue. Those who introduced the theme into public debates were representatives of the cultural and political elite who characterized themselves as nationally minded or nationally committed. They identified as opponents those who sought to keep the topic within the framework of academic investigation in order to avoid the subjective and symbolic reapplication of Trianon. (Zeidler, 2003: 11)

\section{Public history: old mythology for a new nationalism}

While the academic community - represented by researchers working in the fields of political, intellectual, and social history (Ablonczy, 2010; Kovács, 2010 and 2011; Michela and Zahorán, 2010; Romsics 2010; Zeidler ed. 2003; Zeidler, 2002), as well as the sociology of knowledge (Gyáni 2010, 2012) - has maintained a certain distance from the practice of memory-politics, other non-scientific and non-state-run institutions have sought to combine the disciplinary professionalism of historywriting with the project of myth-building. The most important examples of this approach are: the Trianon Museum in Várpalota, the periodicals Nagy Magyarország [Greater Hungary] and Trianoni Szemle [Trianon Review], and popular musicians who place a strong emphasis on historical mythology in their work. Their common ambition is to insist on the recognition of the trauma that Trianon caused for Hungarian national identity and, more broadly, to devise a new type of memory-politics that affirms their understanding of national identity and the "national interest". Their goal, in other words, is to link Hungarian national self-image to Trianon in a way as to undermine interpretations that shadow the issue.

One of the main actors in the field of public history is the Trianon Research Institute, which publishes the Trianoni Szemle. The institute was founded in 2007 by Gyula Fábián, senior journalist at the rightwing daily Magyar Nemzet, Ernő Raffay, professor of a church run university, Gyula Zeke, former cultural radio host and current advisor to the prime minister, and Archimédesz Szidiropulosz, the director of the Institute. The publication of the periodical was initially funded by the local government of Óbuda. Recent applications for state funding were, however, twice rejected by the National Cultural Fund and the relevant parliamentary committees. This prompted the editors to call on the readers of the daily Magyar Hirlap and the viewers of Echo TV to donate money to support the publication. ${ }^{\text {xi }}$ Since 2013, no new issues have been published. 
Archimédesz Szidiropulosz wrote a three volume monograph about Trianon. One of the volumes deals with "the perception of Trianon within Hungarian society," through a collection of interviews with intellectuals, politicians, and public figures (Szidiropulosz 2005). His aim is to examine the relationship between Trianon and national identity and he reaches the conclusion that Hungarian national identity was so severely damaged by the Treaty that it never recovered from the trauma: "Since Trianon, we have always had to explain ourselves; we always get confused when we asked about our homeland, our national belonging. Our national identity has become unsettled and deformed after Trianon. The decades of communism have almost completely eliminated feelings of national belonging in Hungary, while all over the world the most natural feeling shared by people is their sense of national belonging." (Szidiropulosz 2005, 398) Szidiropulosz states that the lack of consensus regarding the question of Trianon is caused by both generational and political factors. According to him, the main problem lies in the "neoliberal" and "global" ideology, which excluded the topic of Trianon from public and scholarly discussions, because their proponents "cannot relinquish the stereotype which holds that every argument about or emotional connection to Trianon represents an extreme position.” (Szidiropulosz 2005, 399)

Far less embedded in professional scholarly networks, yet wanting to play an even more significant role in the shaping of memory-politics, is the Trianon Museum, which was inaugurated on 4 June, 2004, in the Zichy Palace in Várpalota. The building belongs to the Trianon Museum Foundation whose advisory board was initially led by Zsolt Bayer (a founding member of Fidesz and the country's most renowned right-wing journalist). The permanent exhibitions of the Museum commemorate the heroism of Hungarian soldiers during the First and Second World Wars (The relics of Hungarian heroism and bravado); the revisionist movements of the Horthy-regime (About the history of the Hungarian revisionist movements); the national public monuments destroyed after 1918; the poets who sang "the pain of Trianon" and "the joy and enthusiasm" experienced during the short "return of the torn-away territories" after the First (1938) and Second (1940) Vienna Treaties. One of the permanent exhibitions in the Museum commemorates the revisionist movements of the interwar period (invoking many of the slogans of the time: "Hungary does not forget!"; "No revolt. But no compromise either."; "Transylvania is ours."; "Justice to Hungary!"; "What was once, shall be again.”), and the political acts of revision (the "return" in 1938 and 1940 of the territories lost as a result of the Treaty) - interpreting these as moments of national self-realization.

While the left-liberal government that was in power between 2002 and 2010 did not take notice of the initiative, the new Fidesz government developed an ambivalent relationship with the institution. On the one hand, the Museum receives state funding (45 million Forints in 2011, 53 million in 2012). On the other hand, it was not designated as the official commemoration place of the Trianon Memorial Day. Nevertheless the Trianon Museum received overwhelmingly positive coverage in the right-wing media. For example, the that time mainstream right-wing daily Magyar Nemzet greeted the inauguration of the Museum with an enthusiastic tone: "Nearly fifteen years had to pass for the first Trianon Museum to open its doors in Rump Hungary." "xiii

In this section I presented the popular forms of the memory-politics - ranging from the publication of semi-professional historical periodicals to the creation of historical memory sites (labelled as a "museum") - that played an important role in the rehabilitation of the symbolic tool kit, which enabled Trianon to become the mythomoteur of Hungarian neo-nationalism. I argue that the proponents of professional historiography have been side-lined by the enterprise of myth-building in the service of an old-new identity politics. The main purpose of the Trianon-discourse was to transform the approach to national history, in other words, to construct a different kind of memory-politics. Having investigated the field of public history, I now turn to the political field to analyze how memory-politics can be bent to the service of the political will. This analysis will focus on two directions and 
institutional actors within the right-wing political field: the Sixty-Four Counties Youth Movement, which calls for a revisionist solution regarding the question of Trianon; and the Jobbik Youth Movement, which created new festivities focusing on the commemoration of Trianon on the local level with a view to promoting grass-roots mobilization.

\section{Trianon: a taboo-breaking symbol elaborated by the far-right}

The commemorations of Trianon were not initiated by the Hungarian state but various political and civil organizations, all of which belong to the far-right side of the ideological spectrum. The most remarkable commemorative events of the early 2000s were organized by a radical youth organization, the Sixty-Four Counties Youth Movement (SFCYM). In the past few years, however, the local branches of the far right party, Jobbik have also organized Trianon commemorations in many of the towns and villages where the SFCYM has had no activity. As a consequence, the latter organization found itself compelled to increasingly radicalize its discourse with a view to maintaining a competitive edge over Jobbik-led Trianon-festivities, which have targeted families and youth.

The SFCYM received its name from the "sixty-four counties which constituted Hungary before the Trianon Treaty," according to the founders of the movement. It presents itself as "the only organization in the Carpathian Basin that does not recognize the borders drawn after Trianon." As the program of SFCYM states, the goal of the movement is to achieve the revision of the Treaty and the establishment of territorial autonomies. Despite its clear political goals, the organization puts a lot of emphasis on activities related to cultural events, humanitarian action, and "nationally-oriented" education. The movement, under the charismatic leadership of László Toroczkai, played a leading role in the creation of two popular musical and cultural events: the Magyar Sziget [Hungarian Island] and the Székely Sziget [Szekler Island] festivals. These initiatives relied on the dynamic 'national rock' scene as a resource and entrenched the organization as a significant actor on the far-right. (Feischmidt-Pulay 2017)

The SFCYM has forged close ties with Jobbik. During the campaign for the 2010 parliamentary elections, the two organizations signed a cooperation agreement (together with the Magyar Gárda [Hungarian Guard] and other organizations).. The strong collaboration with Jobbik became looser in the time preceding the 2018 elections, but did not prevent the SFCYM from maintaining a distinctive profile. It achieved this through the appropriation of certain themes and stylistic elements, successfully carving out its own unmistakable position on the far-right scene. It organized the first Trianon commemoration on 4 June, 2001, together with the then popular Hungarian Revisionist Movement lead by György Budaházy. In 2005, the SFCYM managed to mobilize a significantly larger crowd for the same commemoration, most likely thanks to the general shift in public opinion towards the right. In 2008, there were already several commemorations, but the SFCYM and Jobbik mobilized by far the largest crowd. The website of the organization featured a map which showed all the locations where commemorations were held simultaneously, mostly in collaboration with Jobbik's local chapters $^{\mathrm{xiv}}$. The SFCYM focused on preparing the Budapest festivities. ${ }^{\mathrm{xv}}$ In the past years, Jobbik has spent additional effort on the installation of monuments in connection to Trianon commemorations. ${ }^{\text {xvi }}$ These commemorations usually take place at the site of the local Trianon memorial-provided there is one. The installation of such monuments was sometimes realized with the help of the church or local government.

The new generation of far right politicians (the so called Jobbik-generation), taking advantage of the popularity of local Trianon commemorations, used its newfound strength and legitimacy to challenge the silencing strategy pursued by left-liberal elites. It thereby established Trianon as a symbol on which 
a novel kind of anti-establishment politics could be built. The official adaption of the symbol by the new right-wing government, and the subsequent political career of the Trianon-cult, attests to the mobilizational power of Trianon. While certain figures within the ruling party - such as Zsolt Bayer played a role in the effort to establish Trianon as a lieu de memoire, the decision to incorporate the commemoration of Trianon into the state's official memory-politics was clearly motivated by the desire to rob an emergent political contender of a powerful mobilizational tool.

\section{Glory and anomie: historical nostalgia as remedy for disempowerment}

In the last section I will address the discursive appropriation of the symbol of Trianon and the socially relevant meanings associated with it. According an opinion poll conducted in 2003 (and repeated in 2007 with similar results), only 10\% of Hungarians thought that the partition of the country in 1920 was the consequence of the politics that the Hungarian state had adopted in relation to ethnic minorities, while 30\% expressed the opinion that the blame should be placed on "the Jews," "the Left" and foreign powers (first of all France). Another poll highlighted the persistent relevance of Trianon. In 2007, half of respondents (twice as much as four years earlier) declared that "they cannot bow to Trianon," meaning that they did not accept the consequences of the Trianon Treaty. (Vásárhelyi, 2007)

Within the framework of a recent study that sought to examine the political attitudes and national identity of young Hungarians, I myself had the chance to talk to members of local Jobbik organizations who were involved in the organization of Trianon commemorations in the period of 2009-2013 (Anonymus 2014). One of my interviewees who was active in the local Jobbik group in Dunaújváros, portrayed the Trianon commemorations as manifestations of community action and as occasions for the public expression of national identity. The leading role played by Jobbik in the organization of such events and in the mobilization of youth for community-related activities was also recognized by interviewees who were not members of Jobbik.

Among young interviewees there was a consensus that the treaty, which "forced Hungary to give up two-thirds of its former territory," constitutes a "national tragedy." In the words of one participant: "This was a gigantic nation, and they cut its legs and arms. They left a small piece in the middle to show that there was once such a thing." The grief caused by this loss is particular in that it possesses significant mobilizational power. Its discussion triggers indignation, hatred, revenge and revolt - emotional responses that can consequently be channelled into hostility towards the nation's enemies and symbolic action aimed at redressing the injustice. Such action is oriented towards the symbolic reconstruction of pre-Trianon Hungary ("Greater-Hungary"), which is portrayed as the natural manifestation of the Hungarian nation's economic, cultural, moral and political supremacy over inferior neighbours.

"Greater Hungary" is not only perceived as the mirror-opposite of contemporary "smaller Hungary" but as a potential rallying 'site' for national solidarity: "Everyone knows somewhere deep inside that Greater Hungary was a good thing. That there is this is small, puny country in Central Europe and that that's no good, and that there was this Greater Hungary, which was a fine thing. So it has in a way become a symbol. That's what has to be destroyed because it creates community. Jobbike would practically not exist if it wasn't for this. If there hadn't been Trianon then there may not have been the kind of patriotic self-defence reflex that we saw in the 1920s. Things would look very different then; Jobbik may not exist at all." This mobilizational potential is exploited in vernacular objectifications of the Trianon-cult such as the car stickers depicting the icon of "Greater Hungary". An online debate conducted in 2010 revealed that the most frequently articulated arguments in support of the stickers' use was that they express solidarity towards Hungarians living in neighboring countries and that by putting them on public display one can contribute to the promotion of "historical truth", 
a kind of everyday memory-politics: "This sticker depicts the old and complete Hungary. If they would teach us the true history, then everyone would know just how our neighbors managed get hold of certain parts of our dear homeland. Throughout the thousand years of Hungarian history, our kings have always considered the entirety of the Carpathian Basin as being one country (which was dedicated to the Blessed Virgin Mary, Patron of Hungary). If someone uses this sticker, all they are doing is giving voice to historical truth."

The online debate referred to above was triggered in 2010 by an article of a well-known historian who currently leads the largest scientific investigation on the memory of Trianon, ${ }^{\text {xviii }}$ Balázs Ablonczy, which was published on the online news portal Origo.bu under the title "Historical Hungary: the sticker of memory." According to Ablonczy: "The loss of these territories—and a sizeable Hungarian population with them — was a historical event that, even today, fills many people with sadness and nostalgia. The enthralment with lost greatness is at the same time an opium and a form of rebellion against conformity ... Those who display the sticker simply want a reminder of the empire. (...) [The sticker] relates to official memory as graffiti relates to canonized art. Yet, in contrast to graffiti, it only appears on one's own property and can always be removed. It is very much like a removable I Love You tattoo." In Ablonczy's view, this manifestation of historical nostalgia does not exist in itself, but is part of an everyday identity (or popular identity politics) which aims to create an object of national pride, that is, a symbol which can redress a battered self-esteem: "They are only trying to demonstrate their affiliations within a society which, in their view, is disintegrating. They want to leave a mark and to find community. The use of the stickers cannot be probibited, and it would not be advisable to do so: those pieces of paper are the signs of social anomie — representing a diversity of emotions, not threats."

Our interviews and the online discussion both highlight the importance of remembering the "Trianon disaster" as well as its direct association with the cultivation of "Hungarianness". Trianon offers an avenue for reasserting personal dignity in a situation of disempowerment. This was brought home to us by the frequent mentioning of "pride", which our interviewees (as well as the participants of the online debate) described as something that they could achieve by: learning and teaching Hungarian history; participating in (or in some cases organizing) commemorative events; wearing or displaying "ancient" and once repressed historical symbols (the map of "Greater Hungary" or the Árpád-striped flag); or listening to a new type of "national rock music" disseminated by an emergent cultural industry.

I am convinced that neither historical nostalgia nor new forms of everyday nationalism can be understood independently from the socio-political context in which they emerge. Referring to the work of Clifford Geertz, several scholars have identified the nation as a narration, "a story which people tell about themselves in order to lend meaning to their social world." (Ram, 1994 referring the Geertz, here Wodak 1999, 23) It is, however, not only meaning that is at stake. Researchers who have attempted to uncover the structural drivers underpinning support for new forms of identity and memory-politics have argued that the success of new right-wing cultural and political entrepreneurs would not have been possible without the presence of economic grievances that compel those who experience them to confront the ideological status quo and its defenders (Kalb, 2011). The narratives of our interviewees also highlighted problems such as the disadvantaged position of labour vis-à-vis capital, the presence of unjustified social inequalities and the state's inability to challenge these suggesting that these play a role in the emergence of neo-nationalist and anti-elitist sensibilities. The analytical focus on issues of collective memory does not diminish (even less refute) the importance of socio-economic factors. Claiming that neo-nationalism is to a large extent driven by a profoundly "frustrated national identity" is not equal to saying that economic matters are irrelevant or secondary. To the contrary: frustrations related to "smaller Hungary" contain both cultural and economic aspects - shaped, amongst others, by the disintegration of perspectives for social mobility and sticking Hungary's position on the periphery of the European Union. 


\section{Conclusions}

This paper started out by recognizing the valuable insights offered by previous researchers who have pointed to the significant role played by memory-politics in post-communist countries. Alongside Ange and Berdahl, Gyáni, Hann, Todorova and Gille I have also argued - through a focus on the rehabilitation of the memory of "Greater Hungary" and "Trianon" in the 2000s-that issues of memory have recently re-emerged as a central focus of public culture. The analysis I presented can be read also as a follow-up to an article published by ethnologist Tamás Hofer in 1992 in which - taking cue from Bourdieu - he analyzed the social functions and embeddedness of symbolic politics (Hofer, 1992). With his analysis in mind I claim that the struggle between emergent elite groups after the change of regime for control over historical symbols and memory was not a unique event. The recent return of the iconography and discourse of revisionism to the public realm suggests that Hungarian society turns to historical symbols in situations of uncertainty. Furthermore, it also demonstrates that when a new generation of politicians sets out to define its position within the Hungarian political arena, it too chooses historical symbols to achieve its goals.

While elite groups played a key role in the establishment of the iconography and memory-politics of the new democratic regime, my analysis highlighted radical right-wing organizations' effort to construct novel lieux de memoire and a counter-hegemonic memory-politics. This effort was centered on the resurrection of the Trianon-trauma through local commemorations of the anniversary of the Trianon Treaty, which had been banned under the state socialist period and continued to be neglected by left-liberal elites after the 'change of regime'. I argued that this strategy was greatly helped by popular forms of memory-politics - ranging from the publication of semi-professional historical periodicals to the creation of historical memory sites. These played an important role in the rehabilitation of a historically loaded symbolic tool kit, which enabled Trianon to become the 'mythomoteur' of Hungarian neo-nationalism. They achieved this by expelling professional historiography and creating space for a historicizing identity politics. The latter was enacted by - typically young - activists associated with the Jobbik party and revisionist movements who began to organize commemorative events in local communities from the beginning of the past decade. Their success in attracting sympathy and a growing number of followers was not only enabled by the proponents of public history but also increasing frustration - gripping wide segments of society - with the project of regime change and the elites who steered the country through the period of transition. The invention of this old-new political tradition could only have a powerful social effect because it was broadcast "on a wavelength to which the public was ready to tune in" (Hobsbawm, 1987: 263). The Trianon-cult in Hungary addressed a widespread need for collective self-esteem and personal pride by providing adherents the opportunity to express grievances, channelling grievance into anger against elite groups and offering an avenue for overcoming personal and collective trauma through the symbolic assertion of national unity and superiority.

The success of 'Trianonization' is most clearly evidenced in the reaction it elicited from the mainstream right. Recognizing the power of the discourse and associated symbols, the right-wing governments since 2010 entrenched the commemoration of the 'national tragedy' as a key element of the state's memory-politics. ${ }^{\text {xix }}$ Although state-sponsored rituals have sought to domesticate a countercultural movement, the narratives focusing on the Trianon-trauma retain a subversive - not to say explosive - potential. This is because as a mythomoteur for present-day Hungarian nationalism the Trianon-cult has set in motion a novel kind of nation-building process. Trianon clearly constitutes a watershed between the political and the ethnic conceptions of nationhood. The example of the renewed Trianoncult shows that radical shifts in politics - in this case, the shift from a presentist republican to a 
historicist ethnic conception of the nation - takes place through the activation of a previously suppressed symbolic repertoire that bears the imprints of its previous uses.

\section{References}

Ablonczy Bálint. 2010. Trianon-legendák. (Legends of Trianon) Budapest: Jaffa, 2010.

Ange, Olivia and Berliner, David. 2015. Anthropology and Nostalgia. New York, Oxford: Berghahn Armstrong, John. 1988. Nations before Nationalism. Chaper Hill: University of North Carolina Press

Çinar, Alev and Has, Hakki. 2017. "Politics of Nationhood and the Displacement of the Founding Moment: Contending Histories of the Turkish Nation" Comparative Studies in Society and History 59 (3): 657-689.

Berdahl, Daphne. 2010. On the Social Life of Postsocialism: Memory, Consumption, Germany. Edited by Matti Bunzl. Bloomington: Indiana University Press.

Brubaker, Rogers and Feischmidt, Margit. 2002. "1848 in 1998: The Politics of Commemoration in Hungary, Romania, and Slovakia" Comparative Studies in Society and History 44 (4): 700-744

Colovic, Ivan. 2002. The Politics of Symbol in Serbia: Essays on Political Anthropology. London Hurst.

Feischmidt, Margit \& Glózer, Rita \& Kasznár Katalin \& Ilyés, Zoltán and Zakariás, Ildikó. 2014. Nemzet a mindennapokban. A nacionalizmus populáris kultúrája. (Everyday Nationalism. The popular culture of nationalism) Budapest: L'Harmattan - MTA Társadalomtudományi Kutatóközpont.

Feischmidt, Margit and Pulay, Gergő. 2017. "Rocking the Nation: the popular culture of noenationalism" Nations and Nationalism 23 (2): 309-326.

Fox, Jon. E. and Miller-Idriss, Cynthia. 2008. "Everyday Nationhood” Ethnicities. 8 (4) 536 - 563.

Gal, Susan. 1991. 'Bartók's Funeral: Representations of Europe in Hungarian Political Rhetoric. Representations of Europe: Transforming State, Society, and Identity" American Ethnologist, 18(4): 440458

Gingrich, Andre and Banks, Marcus. 2006. Neo-Nationalism in Europe and Beyond. Perspectives from Social Anthropology. Berghahn Books.

Gyáni, Gábor. 1993. "Political Uses of Tradition in Post-communist East Central Europe" Social Research, 60/4.

Gyáni, Gábor. 2012a. „A magyar emlékezet helyei és a traumatikus múlt”. (The Hungarian Lieux de Memoire and the traumatic past) Studia Literaria, 2012/1-2. 41-50.

Gyáni, Gábor. 2012b "The Memory of Trianon as a Political Instrument in Hungary Today” Miller, A and Lipman, M eds. The Convolutions of Historical Politics, Budapest - New York, 91-115.

Hann, Chris. 1990. "Socialism and King Stephen's right hand” Religion in Communist Lands, 18(1) 4-24.

Hann, Chris. 2015. "Why Postimperial Trumps Postsocialist: Crying Back the National Past in Hungary. In Ange, Olivia and Berliner, David (eds) Anthropology of Nostalgia: Ethnographic Studies. New York, Oxford, Beghahn, 96-121. 
Hofer Tamás. 1992. Harc a rendszerváltásért szimbolikus mezőben. 1989. március 15-e Budapesten. (Fight over the system change in symbolic dimension) Politikatudományi Szemle, 1992/1: 29-51

Kalb, Don. 2011. Introduction. Headlines of Nation, Subtexts of Class: Working Class Populism and the Return of the Repressed in Neoliberal Europe. In Kalb, Don and Halmai, Gábor ed: Headlines of Nation, Subtexts of Class: Working Class Populism and the Return of the Repressed in Neoliberal Europe. New York: Berghahn, 2011. 1-35.

Kovács, Éva. 2010. “Trianon traumatikus emlékezetéről” (About the traumatic memory of Trianon). In Michela, Miroslav and Zahorán Csaba ed. "Magyarország felbomlása és a trianoni békeszerződés a magyar és a szlovák kollektív emlékezetben (1918-2010)" ("Distribution of Hungary and the Trianontreaty in the Hungarian and Slovak collective memory"). Limes, 4: 47-56.

Michela, Miroslav and Zahorán, Csaba ed. 2010. "Magyarország felbomlása és a trianoni békeszerződés a magyar és a szlovák kollektív emlékezetben” (1918-2010). (“Distribution of Hungary and the Trianon Treaty in the Hungarian and Slovak collective memory”) Limes, 2010/4.

Jeffrey K. Olick and Robbins, Joyce. 1998. "Social Memory Studies: From "Collective Memory" to the Historical Sociology of Mnemonic Practices” Annual Review of Sociology. Vol. 24: 105-140

Romsics Gergely. 2006. “Trianon a Házban: A Trianon-fogalom megjelenése és funkciói a pártok diskurzusaiban az első három parlamenti ciklus idején (1990-2002)" (Trianon in the Parlament. Trianon in the discourse of political parties during the first three parlamental periods) In Czoch Gábor and Fedinecz Csilla (ed) Az emlékezet konstrukciói: Példák a 19-20. száaadi magyar és közép-európai történelemböl. (Construction of memory. Examples from the 19 and 20 century history of Central Europe) Budapest: Teleki László Alapítvány, 35-52.

Romsics Ignác. 2010. “Trianon és a magyar politikai gondolkodás” In: Michela, Miroslav and Zahorán Csaba (ed): Magyarország felbomlása és a trianoni békeszerződés a magyar és a szlovák kollektiv emlékezetben (1918-2010). Distribution of Hungary and the Trianon Treaty in the Hungarian and Slovak collective memory) Limes, 2010/4: 7-16.

Smith, Anthony D. 1988. The Ethnic Origins of Nations. Oxford, Blackwell

Smith, Anthony D. 1999. The Resurgence of Nationalism? Myth and Memory in the Renewal of Nations. In Smith, Anthony D Myths and Memories of Nations. Oxford, Blackwell, 253-281.

Smith, Anthony. 2011. National identity and vernacular mobilisation in Europe. Nations and Nationalism 17 (2): 223-256.

Szidiropulosz, Archimédesz. 2004. Trianon utólete. A magyar társadalom Trianon-képe az ezredfordulón. (The afterlife of Trianon. The Trianon-image of the Hungarian society at the turn of the century) Budapest: Kairosz, 2004.

Thorleifsson, Catherine. 2017. "Disposable Strangers: far right securitisation of migration in Hungary” Social Anthropology Volume 25 (3): 318-334.

Todorova, M. and Gille, Zs eds. 2010. Post-Communist Nostalgia. New York: Berghahn Books.

Vásárhelyi Mária. 2007. Csalóka emlékez̨et: A 20. század történelme a magyar közgondolkodásban. (The history of 20 century in the Hungarian collective memory) Bratislava: Kalligram, 2007. 
Wodak, Ruth; de Cillia, Rudolf; Reisigl, Martin and Liebhart, Karin. 2009 [1999]: The Discursive Construction of National Identity (2nd Edition), Edinbourgh: Edinbourgh University Press.

Zeidler Miklós ed. 2003. Trianon - Nemzet és Emlékezet. (Trianon - Nation and Memory) Budapest: Osiris.

Zeidler Miklós. 2002. A magyar irredenta kultusz a két világháború között. (The cult of irredentism in the interwar period) Budapest: Regio.

Zeidler Miklós. 2010. A revíziós gondolat (The revisionist Thought). Bratislava: Kaligram.

Zempléni András. 2002. „Sepulchral Land and Territory of the Nation: Reburial rituals in Contemporary Hungary". Gergely András A. (ed): A nemzet antropológiáa. (The Anthropology of the Nation) Budapest: Új Mandátum.

Zubrzycki, Genevieve. 2006. The Crosses of Auschwitz. Nationalism and Religion in Post-Communist Poland. University of Chicago Press: Chicago.

Zubrzycki, Genevieve. 2011. "History and the National Sensorium: Making Sense of Polish Mythology" Qualitative Sociology 34: 21-57.

i Available also in English at: http://www.vajma.info/docs/Nemzeti-osszetartozas-torveny.pdf.

ii http://www.solyomlaszlo.hu/beszedek.html

iii The amendment to the citizenship law was voted in May 26, 2010, by the Hungarian Parliament, offering persons with Hungarian ancestry access to Hungarian citizenship without asking them to renounce their present citizenship and without requiring that they take up residence in Hungary. For further details, see http://eudocitizenship.eu/admin/?p=file\&appl=countryProfiles\&f=2013-18-Hungary.pdf; or http://eudocitizenship.eu/docs/RSCAS\%202010_75.rev.pdf.

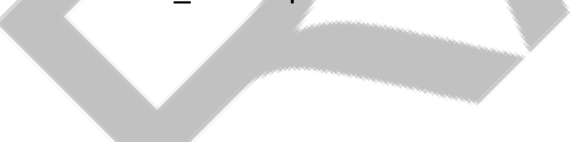

iv The exhibition was closed because the Institute for Hungarian Minorities which gave him place has been moved to a smaller space. Yet, an official explanation has not been given.

$v$ "The institution is devoted to represent national cohesion by strengthening the relationship between Hungarian communities in the country and abroad and to develop a positive image of the Hungarian nation." Excerpt from the mission statement. Source: http://bgazrt.hu/magyarsaghaza/bemutatkozas_en/

vi See www.mimagyarok.com

vii Many thanks for Chris Hahn for the translation of this part of the speech.

viii http://kurultaj.hu/2018/06/a-trianont-feluliro-jovo-elkezdodott-gondolatok-a-gyasznaprol/ 
${ }^{i x}$ I'm greatful to Katrin Kremmler for calling my attention on this junction of Trianon commemorations and the idea of Turanism.

x Publications and reports of the research are available from their webstite: https://tti.btk.mta.hu/lendulet/trianon-100/2579-trianon-100.html

xi In many ways similar to Nagy Magyarország, published by Kárpátia Studio and connected to the website www.tortenelemportal.hu.

xii http://www.magyarhirlap.hu/belfold/meg_is_szunhet_a_trianoni_szemle.html.

xiii http://mno.hu/migr/megnyilt-a-trianon-muzeum-646042.

xiv Media sources reported that in 201247 memorial events took place in Hungary.

Source: http://alfahir.hu/trianon_megemlekezesek_orszagszerte-20120603.

xv In 2010 sixteen national rock bands participated at the event. Source::

http://szentkoronaradio.com/belfold/2010_05_14_iden-nagyszabasu-emlekkoncerttel-egybekotott-trianon-

felvonulas-budapesten-video-

xvi http://alfahir.hu/trianon_megemlekezesek_orszagszerte-20120603.

xviihttp://www.komment.hu/tartalom/20081008-velemeny-nagymagyarorszag-autos-

matricak.html?cmd=gettid\&status=ok.

xviii See: http://trianon100.hu/

xix Most of empirical evidences used for this paper derives from 2009-2013. Historical nostalgia became since 2015 secondary while the enimization and securitization of the nationalist discourse became more pregnant in Hungary, see Thorleifsson 2017. 